\title{
KEMAMPUAN KOGNITIF SISWA DALAM MEMBACA TEKS EKONOMI KELAS XI-IPS K3 DI SMA NEGERI 10 MALANG
}

\section{Riris Dwi Novianti ${ }^{1}$, Mit Witjaksono ${ }^{2}$, Agung Haryono ${ }^{3}$}

1. Economic Education Progam, Faculty of Economics, State University Malang

2. Economic Education Progam, Faculty of Economics, State University Malang

3. Economic Education Progam, Faculty of Economics, State University Malang rdn.novianti95@gmail.com, mit.witjaksono@um.a.id agung.haryono.fe@um.ac.id

\begin{abstract}
Cognitive ability is a behavior that emphasizes the intellectual aspects, as well as the knowledge, understanding, and the thinking of students in learning. To measure the cognitive abilities of students using text reading, the study raced on Revised Bloom's Taxonomy. The purpose of this study was to determine the level of students' cognitive abilities as measured by tests such as reading texts give the economy and about the description. This research uses a qualitative approach research with descriptive phenomenology. The subjects were students of class XI IPSK3 SMAN 10 Malang totaling 29 students. Data collection techniques used in this study include observation, testing, documentation and assessment rubrics. Meanwhile, data analysis includes data reduction, data presentation, and conclusion. Based on the survey results revealed that out of 29 students who take cognitive tests found 29 students who were able to reach a stage of cognitive ability at level $\mathrm{C} 1, \mathrm{C} 2$, and $\mathrm{C} 3$. Of the 29 students who take cognitive tests were seven students were able to achieve levels of $\mathrm{C} 4$ are analyzed, four students on the test 1 that the reading "of the economy in Indonesia is not inferior to other States" and three students on test 2 on the reading "of fuel in one direction". It also happens to students who are different. Of the 29 students who take cognitive tests there are students who are able reach stage is to evaluate the C5 and C6 are creating. From these results, it can be conclusion that the cognitive abilities of students in reading texts economy reached an average level of C3 that apply.
\end{abstract}

Keywords: Cognitive Ability, Bloom's Taxonomy, Reading Text Economic

History of Article:

Received: (05 Januari 2017), Accepted: (13 Februari 2017), Publised: (15 Mare 2017)

Citation:

Kemampuan Kognitif Siswa Dalam Membaca Teks Ekonomi Kelas XI-IPS K3 Di SMA

Negeri 10 Malang [The kognitif capability of student for reading text economy class XI-IPS

K3 Di SMA Negeri 10 Malang] Jurnal Pendidikan Ekonomi, 10(1), 34-39.

(C) UniversitasNegeri Malang 


\section{PENDAHULUAN}

Perkembangan kurikulum pendidikan di Indonesia lebih mengedepankan pendidikan saintifik yang menjadikan kehidupan sehari-hari sebagai acuan dalam proses pendidikan. Salah satunya dengan adanya penilaian hasil belajar kognitif siswa. Saat ini para pendidik cenderung pada nilai hasil ujian sebagai tolak ukur kemampuan siswa, padahal kemampuan kognitif siswa bukan hanya berpacu dari nilai ulangan yang berupa soal-soal melainkan dengan bentuk baru yang dapat lebih memberikan dampak pada kemampuan kognitif siswa tersebut, misalnya memberikan teks bacaan ekonomi faktual. Kemampuan kognitif siswa sangatlah penting dalam untuk siswa menjalankan kehidupanya di sekolah maupun nantinya diluar sekolah.

Menurut Bloom proses kognitif adalah segala upaya yang menyangkut aktifitas otak. Pengertian ini ditegaskan oleh Susanto (2011: p.47) bahwa proses kognitif merupakan suatu proses berpikir berupa kemampuan untuk menghubungkan, menilai, dan mempertimbangkan suatu kejadian atau peristiwa. Proses kognitif berhubungan dengan tingkat kecerdasan (intelegensi) yang menandai seseorang dengan berbagai minat terutama ditujukan kepada ide-ide dan belajar.

Ranah kognitif berisi tentang perilaku-perilaku yang menekankan aspek intelektual, seperti pengetahuan, pengertian, dan keterampilan berpikir. Indikator proses kognitif merupakan perilaku (behavior) siswa yang diharapkan muncul setelah melakukan serangkaian kegiatan untuk mencapai kompetensi.

Menurut Benyamin S. Bloom, dkk (1956) aspek kognitif memiliki enam jenjang kemampuan, yaitu pengetahuan (knowledge), pemahaman (comprehension), penerapan (application), analisis (analysis), sintesis (synthesis), evaluasi (evaluation). Tingkatan-tingkatan dalam Taksonomi Bloom tersebut telah digunakan hampir setengah adab sebagai dasar untuk penyusunan tujuan-tujuan pendidikan, penyusunan tes, dan kurikulum di seluruh dunia.

Seiring dengan perkembangan zaman, Lorin W. Anderson dan david R. Krathwohl menyusun kembali Taksonomi Bloom (2001: pp. 66-88) menjadi enam tingkatan yaitu: mengingat (remember), memahami/ mengerti (understand), menerapkan (apply), menganalisis (analyze), mengevaluasi (evaluate), dan menciptakan (create). Pada tingkatan kognitif ini berkaitan erat dengan hasil belajar intelektual. Pada aspek satu dan dua masuk ke dalam katagori tingkat rendah dan yang ketiga sampai keenam masuk ke dalam kategori kognitif tingkat tinggi.

Untuk mengukur kemampuan kognitif siswa dengan menggunakan teks bacaan, penelitian ini berpacu pada Taksonomi Bloom yang telah direvisi " $A$ Revision of Bloom's Taxonomy of Educatioan Objectives" yang disusun oleh Lorin W. Anderson dan David R. Krathwohl (2001: pp.66-88) yaitu (1) mengingat (2) memahami (3) menerapkan (4) menganalisis (5) mengevaluasi (6) menciptakan.

Penelitian ini sangat penting untuk diteliti karena kita sebagai pendidik harus lebih kreatif dalam hal melakukan penilaian kemampuan kognitif yang di miliki oleh siswa akan memberikan dampak dalam proses kegiatan belajar mengajar yang dilakukan oleh guru. Berdasarkan uraian di atas, maka peneliti tertarik untuk mengkaji lebih dan ingin menuangkan dalam bentuk karya ilmiah berupa skripsi dengan judul "Kemampuan Kognitif Siswa dalam Membaca Teks Ekonomi kelas XI- IPS K3 di SMA Negeri 10 Malang”. Tujuan penelitian ini adalah 
untuk mengetahui jenjang kemampuan kognitif siswa ketika diukur dengan memberikan tes berupa teks bacaan ekonomi dan soal uraian.

Untuk memberikan batasan konteks masalah, maka perlu dirumuskan masalah sebagai berikut: bagaimana kemampuan kognitif siswa dalam membaca teks ekonomi kelas XI-IPS K3 di SMA Negeri 10 Malang ditinjau dari (a) tingkat kemampuan kognitif siswa dalam membaca teks ekonomi (b) tingkat dimensi pengetahuan dan dimensi proses kognitif.

\section{METODE PENELITIAN}

Berdasarkan fokus penelitian yaitu kemampuan kognitif siswa dalam pembelajaran ekonomi, maka pendekatan yang digunakan peneliti adalah pendekatan kualitatif (Creswell, 2012). Penulis menggunakan penelitian kualitatif karena penulis ingin mendeskripsikan hasil penelitian dengan menggunakan katakata tertulis secara jelas. Penelitian ini menggunakan jenis penelitian fenomenologi dengan pendekatan kualitatif deskriptif (Sugiyono, 2008). Peneliti meneliti secara langsung pada subjek yang akan diteliti. Subjek penelitian ini adalah siswa kelas XI-IPS K3 SMA Negeri 10 Malang yang berjumlah 29 siswa yang terdiri dari 15 perempuan dan 14 siswa laki-laki.

Teknik pengumpulan data yang digunakan dalam penelitian ini meliputi observasi, tes, dokumentasi dan rubrik penilaian. Hal ini sesuai dengan uraian Nurbudiyani (2013) dalam penelitiannya bahwa untuk mengukur ranah kognitif menggunakan alat ukur berupa tes pilihan ganda, sedangkan untuk mengukur ranah afektif dan psikomotor menggunakan lembar observasi. Pada penelitian ini, kegiatan analisis data meliputi beberapa hal, yaitu mereduksi data, penyajian data, dan penarikan kesimpulan.

Teknik ini dilakukan untuk menilai jawaban peserta didik dari tes yang sudah diberikan, tes ini berupa teks bacaan mengenai faktual ekonomi di Indonesia. Setelah menerima jawaban dari peserta didik, peneliti mengkatagorikan jawaban peserta didik tersebut yang susuai dengan indikator-indikator yang sudah peneliti siapkan sebelumnya. Penilaian ini bersifat subjektif karena itu peneliti menggunakan tanda centang $(\sqrt{ })$ untuk meminimalisir adanya kerancuan dalam penilaian.

\section{HASIL DAN PEMBAHASAN}

\section{Dimensi Proses Kognitif}

1. C1 (mengingat): Pada kemampuan kognitif tahapan $\mathrm{C} 1$ siswa mampu mengingat isi teks bacaan yang diberikan oleh peneliti. Dari 29 siswa yang ada di kelas, semuanya mampu mengingat kembali isi teks bacaan tersebut. Dalam menjawab soal tersebut Nampak bahwa siswa berusaha mengingat mengenai pengetahuan yang baru saja ia peroleh yaitu teks bacaan yang baru dibacanya. Mengingat berdasarkan inti bacaan siswa mengungkap fakta, konsep dan istilah lainnya pada teks bacaan. Pada teks bacaan pertama yang berjudul "perekonomian di Indonesia tidak kalah dengan Negara lain" siswa menjawab dengan mengingat beberapa fakta yang sudah ada di teks dengan benar dan menggunakan bahasa sendiri. Pada teks kedua "Program BBM satu harga" siswa dapat mengingat konsep mengenai bacaan ekonomi dan tidak menyimpang dari isi teks. 
Jadi dalam kemampuan kognitif pada tahap C1 yaitu mengingat siswa sudah dapat mengingat kembali mengenai pengetahuan yang baru saja ia peroleh tanpa menyimpang dari teks.

2. C2 (memahami): Pemahaman siswa mengenai bacaan ekonomi ini juga sangat baik. Terbukti dengan jawaban siswa yang mengungkap isi teks bacaan tersebut dengan makna pada fakta, konsep atau istilah-istilah dengan menggunakan bahasanya sendiri. Dari 29 siswa dalam satu kelas didapati 29 siswa yang kemampuan kognitifnya pada tahap C2 yaitu memahami. Jadi pada penelitian ini siswa memahami sesuatu hal melalui bacaan yang baru saja ia baca dan mengungkapnya dengan menggunakan bahasanya sendiri.

3. C3 (menerapkan): Teks bacaan yang diberikan kepada 29 siswa dalam kelas XIIPSK3 ini 29 siswa memiliki kemampuan kognitif pada tahap C3 yaitu menerapkan. Siswa dapat menemukan ide-ide baru dan bisa mengungkapkan pendapatnya dalam menguraikan isi teks yang baru saja ia baca. Jadi dalam penelitian ini siswa dapat menerapkan ide-ide pokok tersebut melalui jawaban yang ia tulis dan tidak menyimpang dari bacaan.

4. C4 (menganalisis): Beberapa siswa yang kemampuan kognitifnya sampai pada tahap C4 yaitu menganalisis. Pada tes pertama dengan judul "perekonomian di Indonesia tidak kalah dengan Negara lain didapati dari 29 siswa yang mengerjakan tes hanya 3 siswa saja yang mampu mencapainya. Pada tes kedua dengan teks bacaan yang berjudul "Program BBM satu harga" hanya 5 siswa yang dapat mencapainya. Tahap analisis ini menjadi sulit karena siswa menguraikan tiap-tiap bagian dari konsep dan fakta yang ada di bacaan tersebut, siswa juga perlu untuk memecahkan sebuah permasalahan ekonomi yang sedang terjadi di Indonesia. Dalam penelitian ini siswa yang mampu menganalisis suatu kejadian yang ada di kedua teks bacaan tersebut hanya tujuh siswa saja, dua siswa pada teks bacaan yang pertama, empat siswa pada teks bacaan yang kedua dan satu siswa pada teks bacaan yang pertama dan yang kedua. Sedangkan siswa yang lainnya hanya mampu menguraikan jawannya sampai pada tahap C3 saja.

5. C5 (mengevaluasi): Dari seluruh siswa yang hadir untuk mengikuti tes 1 dan tes 2 tidak ada sama sekali siswa yang mampu menjawab dengan pola piker yang mencapai C5 yaitu mengevaluasi. Pada C5 ini siswa dituntut untuk mengevaluasi yaitu menilai suatu situasi, keadaan, fenomena, pernyataan atau konsep berdasarkan kriteria tertentu. Pada teks pertama dan teks kedua, evaluasi dari suatu kejadian mengenai perekonomian di Indonesia dianggap sulit oleh siswa sehinggan tidak ada yang mampu mengungkapkannya. Kemampuan kognitif siswa pada tahap C5 ini sama sekali tidak ada, 7 dari 29 siswa yang mampu mencapai tahap $\mathrm{C} 4$ tidak ada yang mampu melanjutkan proses kognitifnya ditahap C5.

6. C6 (mencipta): Siswa sangat sulit untuk mencapai tahap C6 ini karena pada tahap ini siswa dituntut untuk mengahasilkan sesuatu yang baru dengan cara menggabungkan atau menyatukan berbagai elemen, faktor atau unsur sehingga mampu terbentuk pola atau struktur yang baru. 


\section{Dimensi Pengetahuan}

Pada dimensi pengetahuan ini siswa memiliki pengetahuan faktual, dimana dari hasil penelitian siswa hanya mampu mencapai tahap C3 saja. Sesuai dengan teori bahwa pengetahuan faktual meliputi elemen-elemen dasar yang harus diketahui peserta didik ketika akan mempelajari disiplin ilmu atau menyelesaikan masalah dalam disiplin ilmu tersebut.

Pada tes pertama dan kedua siswa memiliki pengetahuan yang dasar mengenai bacaan yang diberikan, sehingga dalam menjawab soal tes siswa hanya mampu mencapai tahapan $\mathrm{C} 3$ yaitu menerapkan, belum mencapai $\mathrm{C} 4$, C5 dan C6 yang tahapannya lebih sulit.

\section{KESIMPULAN}

Dari tes mengukur kemampuan kognitif siswa melalui membaca teks ekonomi yang dilakukan pada kelas XI-IPS K3 di SMA Negeri 10 Malang, terdapat beberapa hasil dalam penelitian yang mengukur kemampuan kognitif siswa dalam pembelajaran ekonomi ini, yaitu: 1) Pada dimensi pengetahuan diperoleh bahwa siswa mampu mencapai pengetahuan faktual yaitu dimensi yang menitik beratkan pada pengetahuan dasar dari sebuah informasi yang diperoleh siswa; 2) Pada dimensi proses kognitif diperoleh bahwa kemampuan siswa hanya mencapai C3 yaitu menerapkan sesuatu yang sudah ia ingat (C1) dan yang sudah dipahami (C2) dengan hasil sebagai berikut: (a) Dari 29 siswa yang mengikuti tes kognitif didapati 29 siswa yang mampu mencapai tahap kemampuan kognitif pada jenjang C1, C2, dan C3; (b) Dari 29 siswa yang mengikuti tes kognitif didapati delapan siswa yang mampu mencapai jenjang C4 yaitu menganalisis, tiga siswa pada tes 1 yaitu dan lima siswa pada tes 2 . Hal ini juga terjadi pada siswa yang berbeda-beda dan hanya ada satu siswa yang sama; (c) Dari 29 siswa yang mengikuti tes kognitif tidak terdapat siswa yang mampu mencapain tahap C5 yaitu mengevaluasi dan C6 yaitu mencipta.

Dengan hasil di atas dapat disimpulkan bahwa kemampuan kognitif siswa masih berada pada tahap dasar, yaitu pada pengetahuan faktual dan tahap C3 saja. Hal ini bisa dikarenakan siswa belum terbiasa mendapatkan materi mengenai bacaan ekonomi atau bisa karena siswa sulit untuk menguraikan jawaban serta berpikir tingkat tinggi.

Saran yang bisa diberikan penulis, berdasarkan hasil penelitian ini antara lain: 1) Membaca Teks Ekonomi dapat membantu siswa untuk mengukur kemampuan kognitifnya, guru diharapkan memberikan bacaan teks ekonomi pada saat pembelajaran di kelas untuk membantu mengukur kemampuan kognitif siswa disetiap materi yang diberikan; 2) Bacaan Teks yang diberikan kepada siswa diharapkan siswa sudah mempelajari materinya, kemudian dikaitkan dengan kehidupan sehari-hari. 


\section{DAFTAR RUJUKAN}

Anderson, L.W. dan Krathwohl, D.R (2001) A Taxonomy for Learning, Teaching, and Assesing: A Revision of Bloom's Taxonomy of Educatioanl Objectives. New York: Addison Wesley Longman, Inc.

Bloom, Benjamin S. dkk (1956) Taxonomy of Education Objectives The Classification of Educational Gools Handbook I: Cognitive Domain. New 1 , York: Longma.n.Jnc

Creswell, J. W (2012) Pendekatan kualitatif, kuantitatif, dan mixed. Yogyakarta. Pustaka Pelajar

Nurbudiyani, Iin (2013) Pelaksanaan Pengukuran Ranah Kognitif, Afektif, dan Psikomotor pada Mata Pelajaran IPS Kelas III SD Muhammadiyah Palangkaraya. Pedagogik Jurnal Pendidikan. 8(2), 14-20

Sugiyono (2008) Memahami penelitian Kualitatif. Jakarta: Bumi Aksara.

Susanto, Ahmad (2011) Pengembangan Anak Usia Dini. Jakarta: Kencana 